\title{
Microtooth supernumerary included in Zygomatic root
}

\author{
Supranumerario microdente incluso em raiz de Zigoma
}

Sérgio Bartolomeu de Farias MARTORELLI ${ }^{1}$

(iD) ORCID iD 0000-0002-0251-1475

Érica Passos de Medeiros LACERDA ${ }^{1}$

(D) ORCID iD 0000-0002-0277-6190

Felipe Bravo Machado de ANDRADE²

(i) ORCID iD 0000-0002-5404-5904

\section{ABSTRACT}

A supernumerary tooth is one that is additional. The diagnosis is usually made by clinical exam and routine radiographs, and the majority of such teeth are impacted and asymptomatic, without affect others teeth. The supernumerary teeth, can occur included or impacted. An early diagnosis is important in order to implement a suitable plan of treatment and prevent such complications. Ectopic inclusions occur at about $1 \%$ of the general population and might be present at many diverse localizations. In this article the authors review the literature around the ectopic inclusions and report a case of an intranasal ectopic supernumerary inclusion. The prophylactic surgical removal of the supernumerary teeth is generally the treatment of choice.

Indexing terms: General surgery. Tooth, impacted. Supernumerary.

\section{RESUMO}

Os dentes supranumerários são dentes formados em excesso, cujo diagnóstico ocorre de forma mais satisfatória unindo exame clínico com exames radiográficos, porém a maioria pode ser encontrada somente por meio de radiografias sem a percepção dos efeitos nos dentes adjacentes, tendo em vista que grande parte pode se apresentar irrompidos ou inclusos/retidos e o seu diagnóstico precoce é importante para que haja um plano de tratamento, a fim de se prevenir futuras complicações. As inclusões ectópicas ocorrem em cerca de $1 \%$ da população em geral e podem estar associadas a diversas localizações. No presente artigo, os autores relatam um caso clínico de um dente supranumerário conóide ectópico incluso em raiz de zigoma. A cirurgia profilática desses elementos supranumerários é geralmente o tratamento de escolha.

Termos de indexação: Cirurgia geral. Dente impactado. Dente supranumerário.

\section{INTRODUCTION}

Supernumerary teeth are developmental alterations with regard to the number of teeth, where one or more extra teeth are formed. These teeth may be located in the maxilla or the mandibular, and may be unilateral or bilateral, the majority being retained ${ }^{1}$.

In most cases, supernumerary teeth are asymptomatic, however they may be associated with pain, as well as pericoronitis. Accordingly, the diagnosis is commonly performed via routine $\mathrm{X}$-rays ${ }^{1}$.

The cause is still uncertain, though a number of hypotheses have been proposed, though they have not yet amassed sufficient material to prove the origin of these extra teeth. Of these theories, the most widely accepted is that of the hyperactivity of the dental lamina in the initiation stage, resulting in a new tooth bud. Another hypothesis is that of syndromic association. Complications may also arise due to the presence of these teeth, such as delayed eruption of the teeth, the development of odontogenic cysts, dentin resorption in the adjacent teeth, changes in the position of the permanent teeth, occlusal change, abnormal sequence of tooth eruption, crowding, caries, gum inflammation and periodontal abscesses ${ }^{2-4}$.

Supernumerary teeth can erupt normally in the oral cavity or be retained in the maxillaries, thus being referred to as embedded teeth. They may be partially or totally enclosed inside the bone, either with or without maintaining the entirety of the pericoronal $\operatorname{sac}^{5}$. In addition, supernumerary teeth may be ectopically embedded, that is, they may develop in a region different from the normal position in the dental arch, remaining embedded inside the tissue $^{6}$.

The reported eruption frequency is greater in the deciduous dentition. In the literature, the location is described in various different ways, but the majority of

\footnotetext{
${ }^{1}$ Faculdade de Odontologia do Recife. Rua Artur Coutinho, 143, Santo Amaro, 50100-280, Recife, PE, Brasil. Correspondência para / Correspondence to: SBF MARTORELLI. E-mail: <smartorelli_maxilofacial@hotmail.com>.

${ }^{2}$ Faculdade Mauricio de Nassau. Aracaju, SE, Brasil.

\section{$\checkmark$}

Como citar este artigo / How to cite this article

Martorelli SBF, Lacerda EPM, Andrade FBM. Microtooth supernumerary included in zygomatic root. RGO, Rev Gaúch Odontol. 2018;66(1):82-87. http://dx.doi.org/10.1590/1981-863720180001000113203
} 
studies agree that the anterior maxilla is the area most frequently affected ${ }^{1}$. The permanent dentition is the most affected, and the commonest supernumerary tooth is the mesiodens, mostly small, dysmorphic, cone-shaped and sometimes appearing in twos or even threes. As for the cone-shaped teeth, these are undersize teeth that can also be ectopic ${ }^{1}$.

Treatment ranges from keeping the supernumerary tooth in conjunction with regular $\mathrm{x}$-ray checkups, to surgical removal, the latter being the treatment of choice in the majority of cases, with the aim of preventing the development of problems commonly associated with supernumerary teeth ${ }^{7-8}$.

Given the above, on account of the rarity of the following reported case, and in the absence of similar cases in the literature reviewed, we present the case report of a cone-shaped supernumerary tooth embedded in the root of the zygomatic arch, where the treatment of choice was surgical removal.

Supernumerary teeth are the extra teeth, in each dentition, which are morphologically similar to the teeth in the region where they appear (normally shaped) or may exhibit an anomalous shape that bears no resemblance at all to the group with which they are associated ${ }^{9}$.

The etiology of the appearance of supernumerary teeth has still not been adequately explained, however various hypotheses have been raised to explain it. It may occur due to: hyperplasia of the dentition, heredity, or even local causes such as inflammation, trauma, abnormal pressure or odontogenesis-related disorders. Others believe in the heredity factor due to the occurrence of mesiodens being more frequent in individuals reporting cases within the family. The presence of supernumerary teeth, whether single or multiple in nature, may also be related to syndromes, cleft lip and/or palate, ectodermal dysplasia or cleidocranial dysostosis'1,10.

The theory of hyperactivity of the dental lamina has also been reported as a causal agent in new tooth buds, as a result of the production of an additional follicle, thereby explaining the formation of supernumerary teeth. The continuing proliferation of permanent or deciduous dental lamina, which forms a third tooth bud (the dichotomy theory), combined with the morphogenetic factor in the process of odontogenesis, explains the etiology, in conjunction with the theory of regression to the dentition patterns of primitive man (atavistic tendency) ${ }^{11-13}$.

The genetic influence on the development of these teeth, characterized by the high incidence of bilateral symmetry, as well as the distribution within the family in many instances, has been observed by many authors ${ }^{7}$.

The classification of supernumerary teeth can be made according to morphology and position. In the deciduous dentition, the morphology is usually normal or conical, while in the permanent dentition it is more variable. The classification most frequently used is the one that differentiates these teeth according to morphology into four types: conical teeth (small, cone-shaped and with normally developing roots), tuberculate (multi-cusped, small and with rudimentary roots), supplemental (same as the other teeth in the normal series), and odontoma (irregular format) 1 .

The effects caused by the presence of extra teeth range from the non-eruption of teeth in the normal series, malposition, diastemas, development of dentigerous cysts, headaches, paresthesia, local disorders and resorption of the adjacent teeth. They may also cause several alterations in the development of occlusion, including complications such as crowding, impacted permanent teeth, root resorption, midline diastemas, eruption in the nasal cavity as well as the formation of periapical or follicular cysts ${ }^{1,4}$.

Supernumerary teeth may be embedded, impacted or unerupted. This classification represents those teeth that have incomplete eruption due to a variety of factors such as lack of eruptive force, or where the eruption was obstructed by some physical barrier in its trajectory such as a lack of space due to crowding, premature deciduous tooth loss and partial closure of the corresponding spaces, rotation of the longitudinal axis, abnormal dental morphology, heredity, ankylosis of deciduous teeth, the presence of supernumerary teeth, presence of dense bone tissue or fibrous tissue in the course of the eruption of the canine, history of trauma or injury in the area ${ }^{9}$.

Ectopic, impacted teeth may be deciduous, permanent or supernumerary and be found in the palate, maxillary sinus, nasal cavity, condyle, coronoid process, orbit or ethmoidal sinus. Other unusual locations include the ovaries, anterior region of the mediastinum and retroperitoneal area. In these cases, it is more appropriate to use the term heterotopic embedding. However, the occurrence of these teeth outside the oral cavity is rare, being more common in the oral cavity, affecting approximately $1 \%$ of the general population ${ }^{5}$.

The presence of supernumerary teeth has been reported in the nasal cavities, orbit, maxillary sinus, ovaries, soft palate, incisive suture, eye socket, sphenomaxillary suture, maxillary tuberosity and between the orbit and 
brain $^{1}$.

Supernumerary teeth are usually asymptomatic and diagnosed during routine X-rays. Only 25\% of supernumerary teeth erupt, so it is extremely important to obtain an early diagnosis and establish a correct plan of treatment in order to avoid problems, such as those previously mentioned with regard to these teeth. Panoramic radiographs are essential to these mostly early diagnoses, as there is no other simple radiograph that will provide a better understanding of the overall state of tooth development ${ }^{3}$. Early diagnosis involves carrying out panoramic and periapical radiography in all children in the mixed dentition phase, thereby avoiding functional, esthetic problems with the adjacent teeth. Neville et al. ${ }^{8}$ stated that, if the supernumerary tooth is removed early, there will be spontaneous eruption of the adjacent dentition in $75 \%$ of cases $^{2-3}$.

There have been reports of ectopia, such as embedded teeth in the anterior region of the mediastinum and retroperitoneal area, as well as nasal embedding 5,14-16.

The forms of treatment vary by case and also depending on the patient's condition, and may be multispecialist, involve exodontia, reduction in size through selective abrasion or endodontic, as well as a hemisection with composite restoration. The surgical treatment of extraction of supernumerary teeth is the principal treatment of choice, and should be done as early as possible when the individual is aged between eight and ten ${ }^{1}$.

Surgical treatment may have a number of consequences such as the rupture of vital structures like the vascular-nervous bundle of the adjacent tooth, and paresthesia. In some cases, clinical judgment or the patient's strength may contraindicate surgical removal, in which case regular radiographic checks are mandatory to prevent complications ${ }^{1}$.

\section{CASE REPORT}

Dark-skinned patient, a 15-year-old student from Recife, in the state of Pernambuco, was referred by his orthodontist to the Oral \& Maxillofacial Surgery Clinic of the SASSEPE - IRH (Institute of Human Resources - Healthcare System for Public Servants in the state of Pernambuco). Oral Health Unit for an evaluation for surgery on the embedded third molars and an ectopic supernumerary tooth.

In anamnesis, the mother and patient did not cite any clinical complaint. The patient reported that, on requesting examinations for orthodontic treatment, the Orthodontist noted the presence of an embedded supernumerary tooth and the patient was, accordingly, referred for treatment.

Upon physical examination, he was found to have facial symmetry, and no clinical anomaly in the maxillofacial complex. Teeth 18, 28, 38 and 48 were missing from the arch.

Panoramic X-ray (Figure 1) and Initial Tomogram (Figure 2), evidenced the embedding of teeth 28, 38 and 48. Agenesis of tooth 18 (neither he nor his mother had reported any prior exodontia). Presence of a dense mass in the left maxilla with high contours. Due to the lack of threedimensionality in the two examinations, volumetric conebeam tomography was requested with the aim of localizing the supernumerary tooth topographically. Through this examination, it was possible to locate the aforementioned tooth, which exhibited vestibular contours, situated at the level of the zygomatic pillar (Figures 2 and 3).

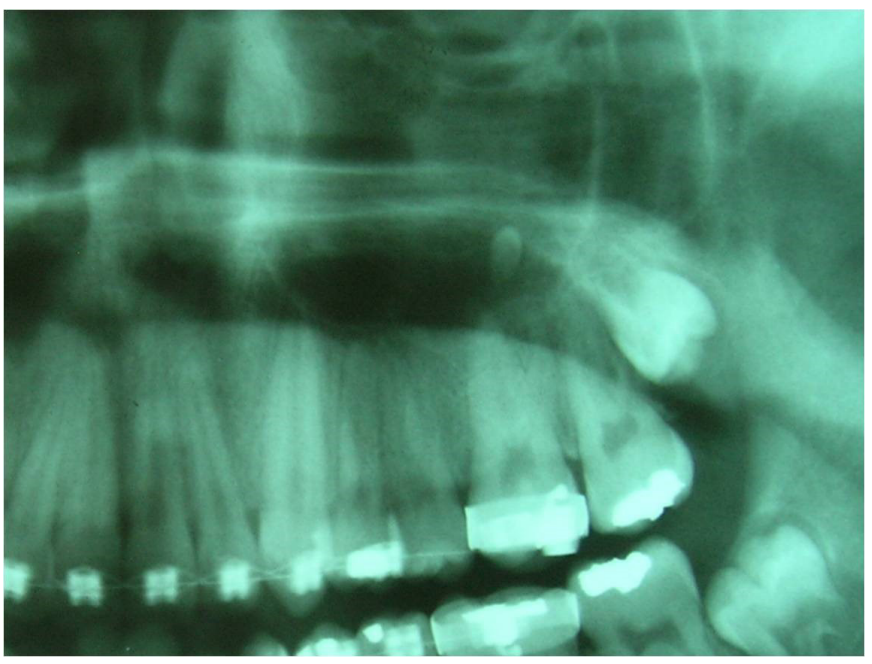

Figure 1. Initial panoramic X-Ray.

Surgery was proposed for the excision of teeth $28,38,48$ and the supernumerary tooth, under general anesthetic, on account of the multiple interventions, expected operative trauma and psychological profile of the patient, as well as the ectopic topography of the embedded supernumerary tooth. All routine preoperative examinations were requested including a cardiological opinion with ECG and surgical risk, all of which fell within normal parameters.

Teeth 38 and 48 were treated using traditional methods. For the surgical treatment of tooth 28 and the supernumerary, it was decided to make a retromolar incision combined with an intrasulcular incision as far as the region of tooth 25 , where a relaxing incision was made preserving the papilla (Figure 4). 


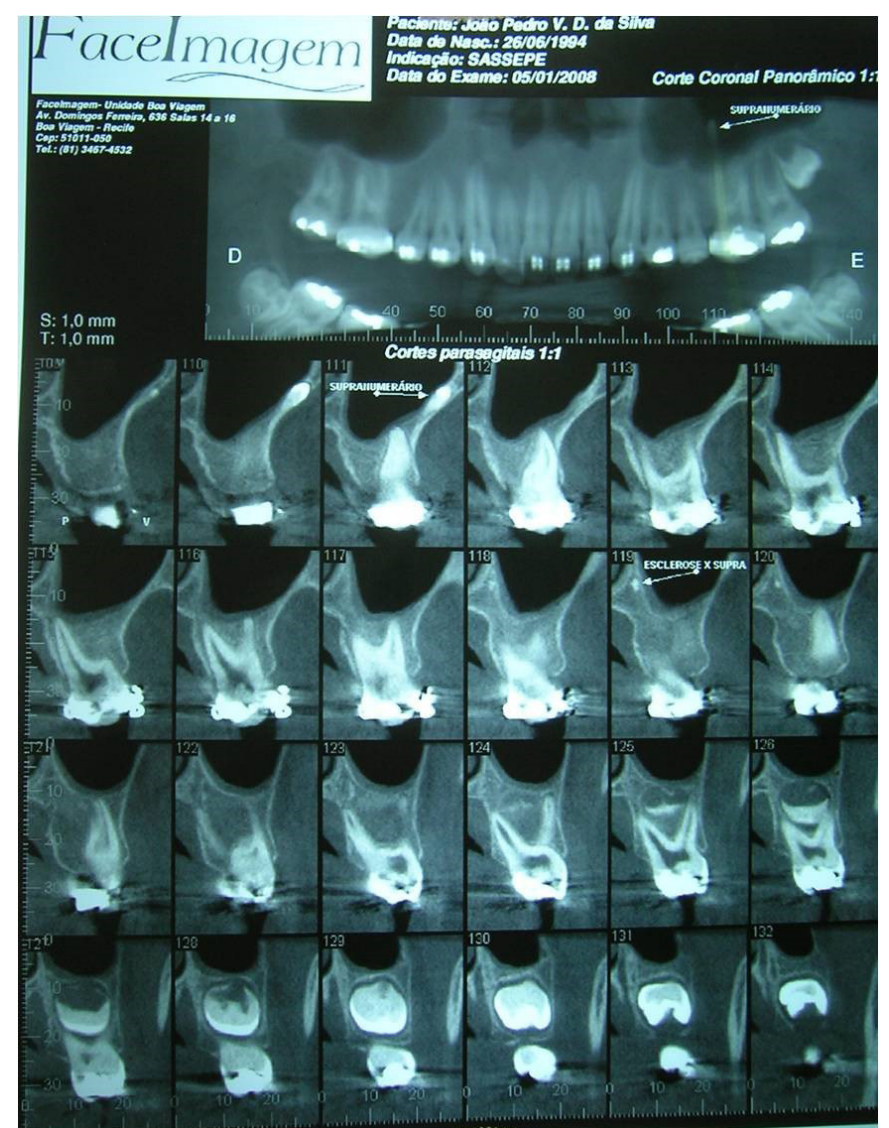

Figure 2. Initial tomograph

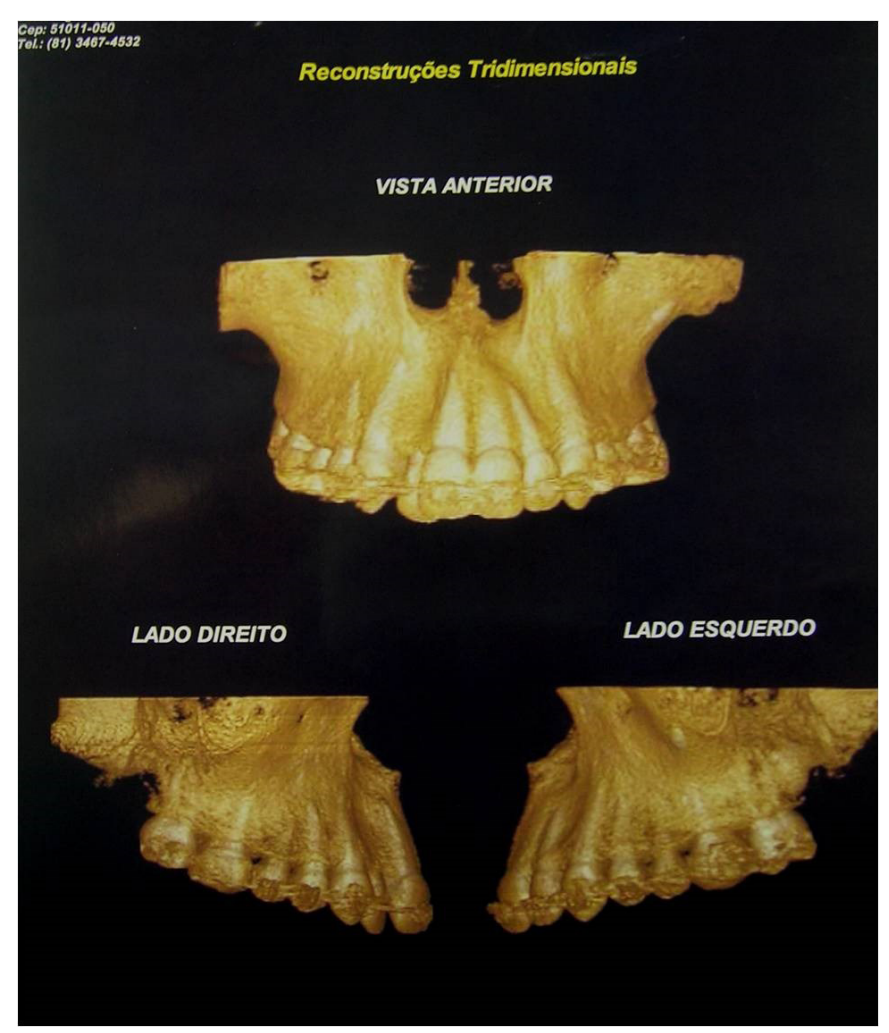

Figure 3. Initial tomograph in 3D.

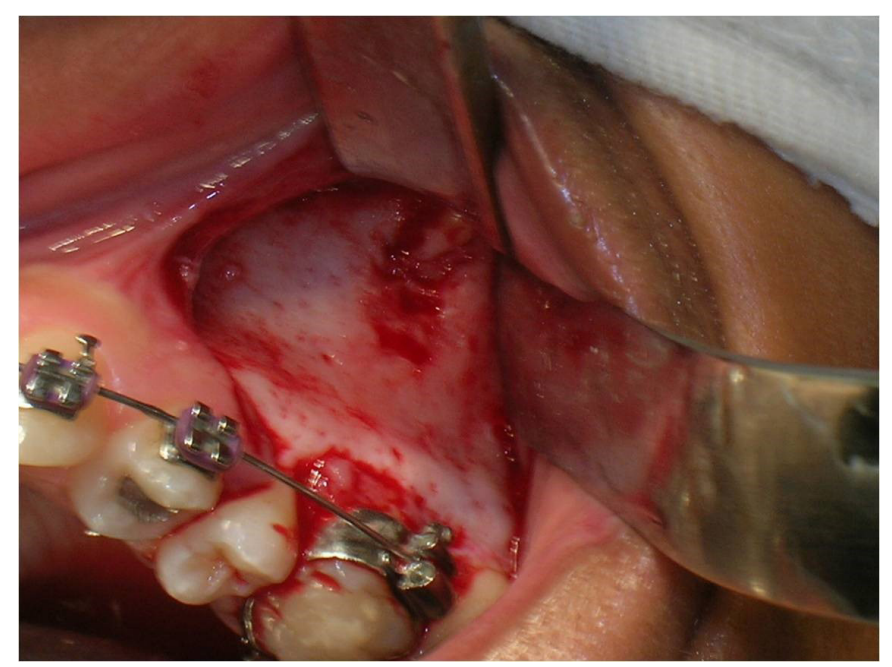

Figure 4. Trans-operative.

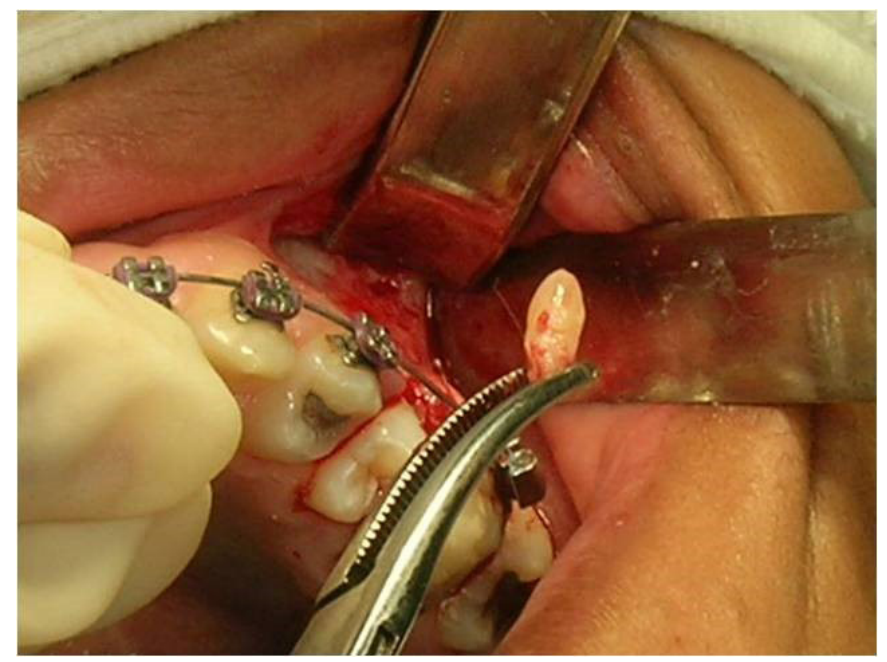

Figure 5. Removal of supernumerary in intra-operative.

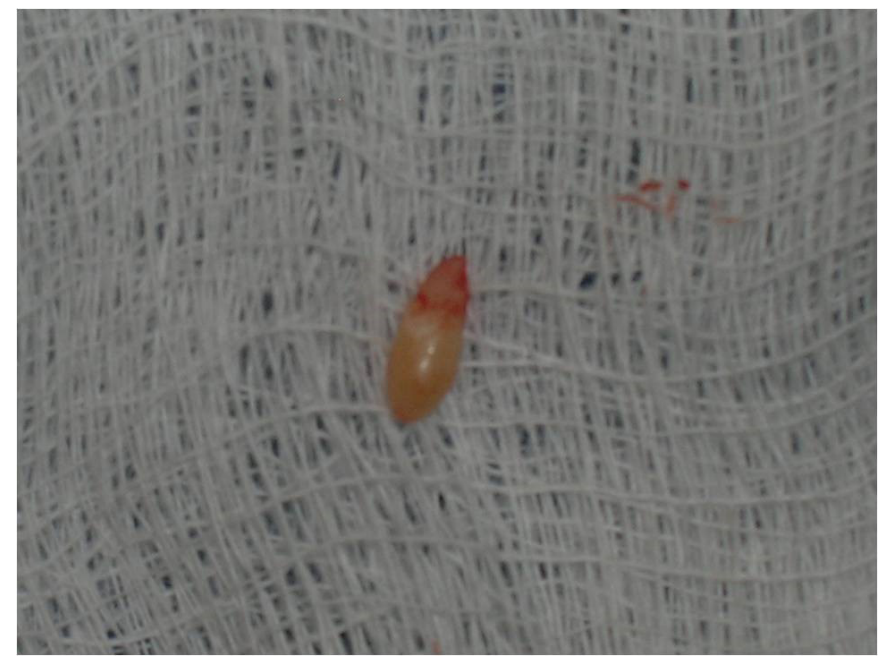

Figure 6. The surgical specimen 
The ostectomy was performed using spherical burs. Following the coronal release of the bone envelopment, using a Heidbrink No. 1 root elevator, the supernumerary tooth was removed (Figure 5 and 6), the pericoronary sac was curetted and, after copious rinsing of the operative field, the region was sutured using 3-0 silk thread.

The postoperative period passed without complication, the stitches having been removed after 1 week.

\section{DISCUSSION}

According to Neville et al. $^{8}$, the majority of supernumerary teeth develop during the first two decades of life, as confirmed by the case reported in this study, in which the patient was diagnosed, when 15-years-old, with a tooth in zygomatic root.

Leite Segundo et al. ${ }^{11}$ believe that, in general, retained supernumerary teeth are detected through routine X-ray examinations. Panoramic radiography (orthopantomography) is an important supplementary diagnostic method, as it provides a good view of the bone structure and dental area, and represents an excellent way to identify supernumerary teeth. This fact corroborates the clinical history reported by the patient, whose embedded supernumerary tooth was identified after a panoramic $X$-ray had been requested for orthodontic purposes.

Soares et al. ${ }^{1}$ studied 61 supernumerary teeth, of which $27(44.26 \%)$ were found in male patients and $34(55.74 \%)$ in females. In 60 cases $(98.36 \%)$, the supernumerary teeth were retained and, in just one case $(1.64 \%)$ it was found to have erupted in the oral cavity. The most common shape of supernumerary tooth was supplemental, in 30 cases (49.18\%), followed by conical in 15 cases $(24.59 \%)$, odontoma in 14 cases $(22.95 \%)$ and, in tuberculate shape in two cases (3.28\%). In terms of the dental arch, there was a prevalence of supernumerary teeth in the mandible, with 35 cases (57.38\%) and 26 $(42.62 \%)$ in the maxilla. These data corroborate the study by Leite Segundo et al. ${ }^{11}$.

Studies carried out by Girondi et al. ${ }^{9}$ found that the highest percentage of supernumerary teeth were coneshaped, in other words the teeth were undersized, those most frequently involved being the upper right lateral incisor, the upper left lateral incisor, upper left third molar and upper right third molar. An undersized supernumerary was also identified in the case reported here.
Marzola 5 believes that the mostadvisable treatment is extraction, with subsequent periodic monitoring. Another option is conservative treatment, involving the preservation of the ST for orthodontic reasons, the decision to do this being quite judicious. The performance of the technique of ST transplant to edentulous regions could also be considered as a treatment mode in specific situations. Various authors are in agreement that early removal of supernumerary teeth is justified due to the interference with eruption or the formation of normal, adjacent teeth, adversely affecting normal occlusal development, giving rise to cystic lesions, or erupting in ectopic positions. ${ }^{3}$ The ectopy related to the reported case was the migration of the supernumerary tooth at the level of the zygomatic pillar, a somewhat unusual situation and hard to find in clinical cases described in the literature.

Fernandes et al. ${ }^{2}$ also believe that the presence of supernumerary teeth could cause a number of problems, such as: eruption failure causing tooth retention, delayed and/or ectopic eruption; impacted permanent teeth, tooth displacement; crowding; impairment of alveolar bone grafts and of implant insertion; associated pathologies, such as odontogenic cysts and tumors, resorption of adjacent teeth, among others. Despite the high susceptibility to supernumerary-related complications, the patient in question had no clinical anomalies in the maxillofacial complex. However, as an orthodontist had requested the removal of the embedded teeth, the treatment of choice for the supernumerary tooth was surgery under general anesthetic, on account of the multiple interventions, expected operative trauma and the patient's psychological profile, as well as the ectopic topography of the embedded supernumerary tooth.

Martorelli et al. ${ }^{6}$ report a clinical case of a 12-year-old female patient with an ectopic, embedded supernumerary tooth located in the left nasal cavity, with no bulging of the palatal or vestibular cortical bone. The treatment performed was the removal of the tooth.

Lee $^{14}$ evaluated 13 clinical cases of intranasal teeth. Of these, seven involved children and six were adults. Moreover, $69 \%$ were in males and $31 \%$ in females. A further 27 cases of intranasal teeth were reported, of which 17 were supernumerary, two being deciduous and 15 permanent.

\section{FINAL CONSIDERATIONS}

The findings of this clinical case were reported 
due to the rarity of the case and the absence of similar case studies in the literature reviewed.

Due to the great susceptibility to supernumeraryrelated complications, preventive surgery was recommended.

\section{REFERENCES}

1. Soares AB, Ferreira-Filho UL, Marzola C, Toledo-Filho JL, Barbosa $\mathrm{JL}$, Haagsma IB. Dentes supranumerários e suas posições no arco dental no município de Curitiba, Paraná, Brasil: prevalência em uma pesquisa de 3000 ortopantomografias [monografia]. Bauru: APCD; 2007.

2. Fernandes AV, Rocha NS, Almeida RAC, Silva EDS, Vasconcelos BCE. Quarto molar incluso: relato de caso. Rev Cir Traumatol Buco-Maxilo-Fac. 2005;5(2):61-6.

3. Solares R, Romero Ml. Supernumerary premolars: a literature review. Pediatr Dent. 2004 Sep-Oct;26(5):450-8.

4. Nayak UA, Mathian VM, Veerakumar. Non-syndrome associated multiple supernumerary teeth: a report of two cases. J Indian Soc Pedod Prev Dent. 2006;24(Suppl 1):S11-4.

5. Marzola C. Fundamentos de cirurgia maxilo facial. São Paulo: Big Forms; 2008.

6. Martorelli SBF, Albuquerque RS, Martorelli FO, Marinho EVS, Coelho Júnior EC. Inclusão ectópica de supranumerário em fossa nasal: relato de caso clínico. Rev ABO Nac. 2009;17(2):4148.

7. Almeida RR, Isbralde CMB, Ramos AL, Terada HH, Ribeiro R, Carreiro LS. Supranumerários -implicações e procedimentos clínicos. Rev Dent Press Ortodon Ortop Maxilar. 1997;2(6):91108.

8. Neville BW, Damm DD, Allen CM, Bouquot JE. Patologia oral e maxilofacial. Rio de Janeiro: Guanabara Koogan; 2004.

9. Girondi JR, Fenyo-Pereira M, Campos PSF, Panella J. Estudo da prevalência das anomalias dentárias de desenvolvimento em

\section{Collaborators}

SBF MARTORELLI, EPM LACERDA and FBM ANDRADE participated in all stages of preparation of the article.

dada população, com o uso de radiografias panorâmicas. Rev Odontol Univ Cid São Paulo. 2006;18(1):15-21

10. Anthonappa RP et al. Characteristics of 283 supernumerary teeth in southern Chinese children. Oral Surg Oral Med Oral Pathol Oral Radiol Endod. 2008;105(6):e48-54. doi: 10.1016/j. tripleo.2008.01.035

11. Leite Segundo AVL, Faria DLB, Silva UH, Vieira ITA. Estudo epidemiológico de dentes supranumerários diagnosticados pela radiografia panorâmica. Rev Cir Traumatol Buco-Maxilo-Fac. 2006;6(2):53-56.

12. Lin $Y T$, Chang SW, Lin YTJ. Delayed formation of multiple supernumerary teeth. J Dent Sci. 2009;4(3):159-164. doi: 10.1016/S1991-7902(09)60021-0

13. Džemidži囚 V, Filipovi囚 M, Tiro A, Nakaš E, Šalaga S. Multiple supernumerary teeth not associated with complex syndromes: a case report. Acta Stomatol Croat. 2009;43(3): 248-255.

14. Lee FP. Endoscopic extraction of an intranasal tooth: a review of 13 cases. Laryngoscope. 2001;111(6):1027-31.

15. Shafer W, Hine MK, Levy BM. Patologia bucal. $4^{\text {a }}$ ed. Rio de Janeiro: Interamericana; 1985.

16. Kirmeier R, Truschnegg A, Payer M, Malyk J, Daghighi S, Jakse N. Int J Oral Maxillofac Surg. 2009;38(11):1219-22. doi: 10.1016/j. ijom.2009.06.013 